\title{
Killings of Police in U.S. Cities since 1980: An Examination of Environmental and Political Explanations
}

Stephanie L. Kent

Cleveland State University, s.l.kent59@csuohio.edu

Follow this and additional works at: https://engagedscholarship.csuohio.edu/clsoc_crim_facpub

Part of the Criminology Commons, Quantitative, Qualitative, Comparative, and Historical Methodologies Commons, and the Social Control, Law, Crime, and Deviance Commons

How does access to this work benefit you? Let us know!

Publisher's Statement

(c) 2010 Sage Publications

\section{Original Citation}

Kent, Stephani L. (2010). Killings of Police in U.S. Cities since 1980: An Examination of Environmental and Political Explanations. Homicide Studies, 14(1), 3-23. doi:10.1177/1088767909353258

\section{Repository Citation}

Kent, Stephanie L., "Killings of Police in U.S. Cities since 1980: An Examination of Environmental and Political Explanations" (2010). Sociology \& Criminology Faculty Publications. 64.

https://engagedscholarship.csuohio.edu/clsoc_crim_facpub/64

This Article is brought to you for free and open access by the Sociology \& Criminology Department at EngagedScholarship@CSU. It has been accepted for inclusion in Sociology \& Criminology Faculty Publications by an authorized administrator of EngagedScholarship@CSU. For more information, please contact library.es@csuohio.edu. 


\title{
Killings of Police in U.S. Cities since 1980: An Examination of Environmental and Political Explanations
}

\author{
Stephanie L. Kent ${ }^{\prime}$
}

\begin{abstract}
Most research on killings of police in urban areas attempted to link lethal violence against officers to the violence and disorder in the communities they work.Yet support for this relationship is inconsistent. Fewer studies considered whether local political arrangements affect killings of police. This study attempts to remedy this gap by using recent data to investigate the relationship between the political conditions of large U.S. cities and the number of homicides of police officers in the line of duty in the years 1980, 1990, and 2000. Negative binomial regression analyses suggest that racial income inequality and the size of the Black population are positively associated with killings of police but cities with African American mayors have less killings. Police killings of citizens are also positively related to officer killings. The results largely support political explanations and uncover time-contingent effects of segregation on violence against state representatives.
\end{abstract}

\section{Keywords \\ police, homicide, racial threat, social control}

What macrosocial factors predict lethal violence against the police? The research on this topic has produced disparate findings depending on the unit of analysis or period studied (see Kaminski, 2004 for a comprehensive review), but many criminologists report a relationship between the level of community violence and occupational risk of death. In other words, lethal violence against the police may result from working with dangerous populations.

'Cleveland State University, Cleveland, $\mathrm{OH}$

Corresponding Author:

Stephanie L. Kent, Department of Sociology, Cleveland State University, 2I 2 I Euclid Avenue, Rhodes Tower I72I, Cleveland, $\mathrm{OH} 44$ I I5-22 I4

Email: s.I.kent59@csuohio.edu 
Fewer studies have tested whether the political arrangements of cities are related to killings of police. Criminologists have expended considerable effort testing whether political factors contribute to social control efforts like police use of force against citizens but rarely consider whether political arrangements are associated with violence against those who represent or apply social control. This perspective suggests that the economic and political subordination of some groups may lead to killings of officers. Stemming from the views of Weberian sociologists and neoMarxists, violence against the state can be viewed as latent protest against authority (Weber, 1968). The police are the most visible representatives of the state (Bayley, 1985) and a main responsibility of all law enforcement officers is to control what many consider the "dangerous classes" (Garland, 1990). This responsibility is heightened in places where larger differences between the rich and poor exist because the poor will be more likely to resist such highly stratified arrangements. As the police are the most accessible governmental representatives, violence against officers is one outlet for resentments in poor communities.

This association is political if the assumption that political power is based on economic resources holds (Collins, 1975; Weber, 1968). If this logic is correct, economically disadvantaged groups are less likely to have the political power necessary to express grievances through conventional channels and may therefore use violence as a means to make their political opinions known (Jenkins \& Schock, 1992). The addition of racial minority status to class disadvantages should make the problem of access greater and violent political reactions more probable because relative deprivation along racial lines will be more conspicuous (Boswell \& Dixon, 1990; Tilly, 1978). This study will examine the following research question: Is high economic inequality between Blacks and Whites related to violence against the police?

Racial composition independent of income differences may also be related to killings of police. Racial minorities in U.S. cities are more likely to be economically disadvantaged, suffer from relative deprivation compared to their White counterparts, and perceive these existing social arrangements as unfair. Law enforcement officers in places where the greatest economic and political subordination exists and where it is concentrated should experience more personal violence. Based on this logic, two additional research questions emerge: Are killings of police related to the proportion of racial minorities and does this effect vary when this politically weak group is segregated from more powerful Whites? In addition, are increases in political power among racial minorities associated with decreases in killings of police?

Although racial and economic cleavages likely explain some killings of police, political subordination need not represent the only possibility. Violence directed at the police may be an extension of a community's overall level of crime and disorder. This means that officers killed should be related to urban conditions such as violent crime and structural disadvantages that breed crime (Sampson, 1987; Sampson \& Wilson, 1995). If this is the case, these community attributes should be strong predictors of officers killed after political effects are held constant. 


\section{Previous Research}

Several important studies contributed to current knowledge about macrolevel factors related to police killings. But there are numerous shortcomings associated with each. First, results seem to depend on the chosen unit of analysis. Peterson and Bailey (1988), for example, studied states, and Kaminski (2008) analyzed counties, which may have obscured local characteristics that affect killings of police. Several recent studies suggest that the race of the mayor (Jacobs \& Carmichael, 2002) or racial composition of city council (Kaminski \& Stucky, 2009) are related to killings of police in large U.S. cities, but a county- or state-level analysis cannot test for these important relationships. As this study is concerned with potential effects of city political arrangements on killings of police, an analysis of cities is most appropriate.

Second, prior studies used limited measures for explanatory factors. To test the proposition that violence against the police is a result of the violent populations they must control, most studies used crime rates to assess community violence. But this is an indirect measure of the physical threat police encounter. A more direct way to gauge workplace violence is by the frequency the police justifiably use lethal force against community members. Police use of force not only is indicative of a violent population but also suggests that some violence against the police may be retaliatory. When police are seen as using violence unjustly, citizens in turn may respond with violence directed at officers. Although time-series correlations between killings of citizens by police and killings of officers are not strong, this factor may have independent effects on officers killed after other factors have been held constant. A relationship between killings of citizens by police and subsequent homicides of officers at the macro level does not necessarily suggest retaliatory motives at the microlevel, but using killings of citizens by police as a measure of risk thus is worth further consideration as few studies assessed this plausible relationship.

Finally, prior studies only investigated one time period which poses several problems. First, cross-sectional studies employed different lags depending on the years chosen. For example, although Jacobs and Carmichael (2002) and Kaminski and Stucky (2009) aggregated killings of police over several years, explanatory variables are only measured in one year. The former study used factors measured in 1980 to explain homicides of police aggregated over 9 years whereas the latter study's extension used information from 1990 to predict homicides from 1985 to 1995. A pooled time-series cross-sectional analysis improves on the above strategy by using data that incorporates overtime variation. Second, important findings may be restricted to the years analyzed. For example, Jacobs and Carmichael (2002) found that cities with African American mayors had less killings of police. As noted, they analyzed killings from 1981 to 1990 using data from 1980 for explanatory variables, a year in which there were only 11 cities with Black mayors. In the sample analyzed in this study, there were 24 cities with Black mayors in 1990 and 11 in 2000. Perhaps findings limited to the 1980s may not hold in latter years. To discover whether this is true, and to ensure 
that period idiosyncrasies do not distort findings, a study of a large sample of U.S. cities over multiple periods should add to our knowledge about these relationships. Finally, an analysis of multiple periods will also provide more statistical variation and increased statistical power due to a larger number of cases and may reveal timespecific effects of explanatory factors that could not be detected in studies like Jacobs and Carmichael (2002) or Kaminski and Stucky (2009). ${ }^{1}$ This study therefore overcomes major shortcomings of prior research.

\section{Theory and Hypotheses}

\section{Political Explanations}

Economic inequality. Racial and economic disparities likely produce political divisions because those who are economically disadvantaged are particularly likely to be politically excluded (Blalock, 1967). Studies of civil disorders find that groups excluded from mainstream politics are more likely to use violence and this probability increases when political exclusion falls along racial lines (Boswell \& Dixon, 1990; Jenkins \& Schock, 1992; Tilly, 1978). To address the first research question, whether economic inequality between Blacks and Whites is related to violence against the police, my examination of racial inequality combines reactions based on both racial and economic divisions. A focus instead on only economic inequality ignores racial differences and implies that the economic differences between poor Whites and the affluent and differences between poor Blacks and the affluent have identical effects on violent responses directed against the police. If differences in disadvantage based on race lead to differences in political power that leave the poor with no legitimate access to express grievances other than overt conflict, enhanced violence against the police should follow.

Previous studies of killings of police in the line of duty find mixed support for this argument. Kaminski and Stucky (2009) do not find an effect of Black-White income differences, but Jacobs and Carmichael (2002) find that the most important factor contributing to these killings is the gap between White and Black incomes. The latter study suggests that political and economic subordination as measured by racial income inequality should be included in studies that analyze killings of police. A logical hypothesis is that when economic differences between the races expand, the likelihood of violence against police should increase.

Racial threat. I draw on racial threat theory to address the second research question, whether killings of police are related to the proportion of racial minorities. This theory suggests that racial conflict will increase in places with large populations of racial minorities (Blalock, 1967). LaFree, Drass, and O'Day (1992) suggests that as some Blacks continue to have increased "access to opportunity" in terms of economic wellbeing, educational attainment and family stability, crime by this group still increased partly due to an increasingly polarized Black underclass. Thus, as Geller and Scott (1992) suggest, "As some blacks have risen dramatically in educational accomplishment, 
those left behind increasingly come to understand that society sees them as secondclass citizens" (p. 203). Where these disadvantages and the resulting frustration exist it should be more difficult for police to control a relatively large population that threatens social order and may produce added violence. Because lethal violence against the police should be enhanced in cities with larger minority proportions, I expect that the number of homicides of police will be greatest in cities with larger African American populations. Prior studies support this claim. Bailey and Peterson (1994) found a positive effect of the size of the Black population on national rates of homicides of police whereas Jacobs and Carmichael (2002) find that the number of officers killed is greater in the largest cities with the most Blacks.

\section{Segregation}

The second research question also proposes that the effect of racial threat may vary when politically weak minorities are segregated from more powerful Whites. If the political exclusion of racial minorities based on economic resources leads to violence against the police, this violence should be enhanced in places where segregation is most apparent. Spatial segregation by race enhances group differences especially because Blacks are most often concentrated in the most economically disadvantaged regions within cities (Massey \& Denton, 1993). Research finds that segregation positively affects violent crime in urban areas (Krivo \& Peterson, 1996). Accordingly, in the most racially stratified cities, state authorities who serve to control an underclass that is predominantly African American more often will be targets of lethal violence.

Other researchers have proposed that officers are less likely to aggressively police neighborhoods with high concentrations of racial minorities and practice "benignneglect" by avoiding African American neighborhoods (see Liska, 1992 for discussion). Kent and Jacobs (2005) find that the most segregated cities with the highest concentrations of African Americans have smaller per capita police forces. If this logic is correct and departments are not likely to police ghetto neighborhoods as vigorously when residential segregation is pronounced, the likelihood of police victimization in the most racially segregated cities should be reduced. This account suggests that segregation may have a negative effect on killings of police.

Although both positive and negative effects of segregation are plausible, prior studies suggest that the relationship between segregation and killings of police is inconsistent (Kaminski, 2004), and no prior study considered whether the association between segregation and killings of police is consistent over time. Since the early 1990s, police departments attempted to incorporate new policing strategies. Police departments in large cities became more concerned with community policing and, later, public order policing. ${ }^{2}$ These programs typically require a concentration of personnel in places where crime rates are highest, which in large cities are often the places with the highest concentrations of African American. Although surveys of police departments suggest that many cities implemented these programs, it is unclear whether these programs translate to significant changes in daily police work (Weisburd, Mastrofski, McNally, 
Greenspan, \& Willis, 2001; Weisburd, Mastrofski, Greenspan, \& Willis, 2004). Yet testing interactions between segregation and time period is worth further examination. If departments use community-based policing strategies, officers cannot neglect entire neighborhoods, so a hypothesis that they can avoid contact with racial minorities is less plausible at least in recent years as these strategies became increasingly used. In other words, it is possible that the "benign neglect" hypothesis is less plausible in the 1990s and 2000s. Based on this logic, a negative effect of segregation should be limited to earlier years before policing techniques became more community-based so segregation will have a positive effect on killings of police in later years.

Local political arrangements. Most of the prior hypotheses suggest that because racial minorities have the least access to traditional political outlets to express grievances, police killings are more likely when racial minorities are involved. These explanations are plausible because Blacks may direct lethal violence against the police at a rate that is disproportionately high (Jacobs \& Carmichael, 2002). National statistics for the time period analyzed here suggest that in incidents in which the offender's race is known, 39\% of officers are killed by Black offenders (Law Enforcement Officers Killed and Assaulted [LEOKA], Federal Bureau of Investigation [FBI], various years).

To address the final research question, whether an increase in political power of racial minorities is associated with a decrease in killings of police, it is important to consider the degree to which African Americans control city politics. For example, the presence of an African American mayor should decrease the violence directed at government agents such as the police.

The theory behind this proposition stems from explanations for race-based violence. LaFree (1982) and others claim that violence committed by African Americans against Whites may be largely explained as a reaction to Blacks' feelings of powerlessness. If this is the case, then it is possible that when African Americans gain political power, these feelings of powerlessness and the associated violence will decrease. In fact, some have argued that interracial conflict decreases when Black mayors are present because a racial minority in office suggests that the power of White elites is diminished (Clark, 1994). Research seems to support this idea. Bobo and Gilliam (1990) find that in cities with Black mayors, minorities are more confident about their political influence and efficacy. Lane (1997) notes that Black homicide rates increase when this group loses political influence whereas Jacobs and Wood (1999) report that killings of Whites by African Americans are reduced in cities with Black mayors.

These findings suggest that in cities where African Americans hold the most important political office, Black political efficacy should increase and inclinations to violently strike out against the most accessible social control agents should decrease. It follows that less killings of police can be expected in cities with Black mayors. This hypothesis is plausible because national statistics report that offenders who kill police officers are more likely to be African American than their total percentage of the U.S. population. Although data on the races of those involved in each killing are not available, the Bureau of Justice Statistics reports that $43 \%$ of felons who murdered police from 1976 to 1998 nationally were African American. Studies of specific cities report 
that Black officers are disproportionately shot by civilians and are disproportionately likely to shoot citizens (Geller \& Karales, 1981).

Yet two recent studies disagree on whether having a Black mayor is associated with reduced killings of police. While Jacobs and Carmichael (2002) find that Black mayors are associated with lower numbers of killings across numerous model specifications, Kaminski and Stucky (2009) do not find this effect. Both of these studies examine killings of police in the 1980s and 1990s. To clarify this important discrepancy, this relationship should be considered in the present analysis.

In sum, the results of past research on politically motivated violence suggest that latent political explanations based on economic and racial threat in segregated areas along with local political arrangements should partly explain killings of police. However, this analysis uses aggregate data and thus cannot assess the mechanisms through which political subordination results in homicides of individual officers. Other macrolevel analyses of violence based on antagonisms due to racial or economic subordination argue that these types of reactive violence are not completely rational but instead are products of inarticulate resentment and frustration (e.g., Jacobs \& Wood, 1999; LaFree \& Drass, 1997). Accordingly, if killings of police are at least partly based on political arrangements, then a macrolevel study may be the only way to demonstrate, outside of potentially idiosyncratic case studies, that some killings of police result from political inequality.

\section{Competing Explanations: Environmental Violence Hypotheses}

Violent crime. Police officers in urban areas routinely confront criminal situations that may result in injury or death. If killings of police result from officers' encounters with offenders engaged in criminal activity, places where criminal behavior is most apparent should also have more killings of police. Qualitative studies of policing suggest that this link is obvious. Fyfe (1997) observes that officers must deal with citizens and their problems under conditions that produce violence. The nature of policing is such that officers can easily find themselves in a position in which they must simultaneously protect the public, maintain their personal safety, and subdue a violent citizen. Given the frequency of death in these situations, officer risk may be high during arrests when officers must subdue a potentially violent subject and insure the security of bystanders while avoiding personal harm.

Early quantitative studies examined bivariate correlations between crime and homicides of police and reported that states (Cardarelli, 1968; Lester, 1978) and cities (Lester, 1982) with a high rate of police officers killed by citizens also had high rates of civilians killed by police officers, and higher overall murder rates. More sophisticated multivariate studies report mixed results. Peterson and Bailey (1988) found little to no support for a relationship between killings of police and violent crimes, whereas Jacobs and Carmichael (2002) reported positive relationships between violent crime rates and police killings and Kaminski (2008) found that the city-level arrest rate for serious crime was positively related to police homicide risk. Based on theory and prior 
research and because homicides are the most accurately measured violent crime, cities with the highest murder rates should have more killings of police officers.

In addition to the overall level of violence police encounter on the street, an increase in killings of police following police killings of citizens would suggest that citizens target the police in retaliation to use-of-force incidents. Although individual motivations for killing officers cannot be illustrated in a macrolevel analysis, there is evidence of rationality among at least some who kill police. Meyer et al. (1981) report that those who kill police are less likely to be under the influence of alcohol or drugs compared to offenders who commit less serious offenses against the police. Whether violence against the police is rational or inarticulate, police may be at a higher risk of death in places where citizens see officers as heavy-handed. According to this logic, places with high rates of killings of citizens by police should have more killings of police.

\section{Sources of Unmeasured Crime and Disorder}

It is probable that other environmental characteristics that lead to violent acts not enumerated in official crime rates capture variation in killings of police. Urban conditions like low median family income, high unemployment, and poverty are associated with increases in interpersonal violence and public disorder. But much interpersonal conflict in cities is not reported to the police and is not included in official crime reports. In addition to violence associated with the general crime rates, these indicators of structural disadvantage contribute to disorderly behavior that may influence the amount of violence police are subjected to (Jacobs \& Carmichael, 2002). Prior studies find support for these claims. Peterson and Bailey (1988) found that independent of violent and property crime rates, states with the highest poverty rates had more killings of police. They concluded that "police work is more hazardous in jurisdictions with high levels of poverty, regardless of the general crime rates" (p. 230). For these reasons, it is probable that in cities with lower median family income, higher unemployment, and larger percentages of families in poverty, there will be more lethal violence directed at the police.

\section{Controls}

Killings of police should be less probable in places where the perpetrator is likely to be caught. Studies provide evidence that violent crime is more prevalent in the largest cities (Mayhew \& Levinger, 1976), probably because increased anonymity in populous places makes identification and arrest more difficult. If this anonymity decreases the chances that perpetrators will be apprehended, I expect killings of officers to be more numerous in the largest cities. Any study of killings of police should also control for the population at risk. Killings should be higher in cities with more police. Finally, controls are included for unmeasured regional and year-specific effects by including dummy variables for 8 out of 9 census-defined regions and 2 out of 3 periods analyzed. 


\section{Method}

\section{Data and Measures}

The data include information for all U.S. cities whose population was greater than 100,000 in 1980 for the years 1980, 1990, and 2000. These periods were chosen because much of the data for the explanatory variables come from the decennial censuses. Limiting the sample to large cities only is acceptable because previous research finds that the largest cities pose the greatest danger for the police (Cardarelli, 1968). National statistics for the most recent period analyzed (2001-2003), 25\% of officers killed are employed in agencies that serve cities with more than 100,000 people.

The dependent variable, killings of police, is measured using the number of homicides of police in the line of duty from the FBI's LEOKA series available from the University of Michigan's Inter-University Consortium for Political and Social Research (ICPSR). This source reports killings of officers by department and has been used in prior investigations (e.g., Jacobs \& Carmichael, 2002; Kaminski \& Stucky, 2009). LEOKA data were used because these data are reported from departments directly to the FBI. The alternative data on killings of officers from the Officers Down Memorial Web page includes accidental deaths. As this study focuses on violence directed by citizens against police, LEOKA data are most appropriate.

Measures for independent variables are from the U.S. Census and the Uniform Crime Reports (FBI, various years). The political variables used to address the four research questions include the ratio of Black to White incomes, the percentage of Blacks, Black-White segregation, and a dummy variable indicating whether the city has a Black mayor supplied by the Joint Center for Political Studies. ${ }^{3}$ Environmental violence measures include justifiable police killings of citizens from the FBI's Supplemental Homicide Reports, measured as a rate per 100,000 residents, and the city murder rate. ${ }^{4}$ The square roots of each of these are used due to their skewed distributions. Other structural factors that may contribute to a violent working environment are gauged with the real median family income (adjusted to account for changes in the value of the dollar over time), the percentage of families below the poverty line, and the unemployment rate. To gauge the population at risk, I include the number of sworn officers. The log of this number is included because larger departments typically have more funds to allocate to administrative positions, leaving a lower proportion of officers on street duty (Jacobs \& Carmichael, 2002). ${ }^{5}$ Other controls include city population and dummy variables indicating census region and year.

\section{Estimation}

Explanatory variables for 1980, 1990, and 2000 (with the exception of income data which are available only for the years 1979, 1989, and 1999) are used to predict counts of homicides of police in cities in 1981-1983, 1991-1993, and 2001-2003. By summing these counts over each of these 3-year periods, idiosyncratic events will be less likely 
to distort the findings (see Jacobs \& Carmichael, 2002 for precedent). In addition, including periods separated by multiple years in a pooled time-series design substantially reduces serial correlation and the effects of measurement error (Johnston \& DiNardo, 1997). To eliminate serial correlation, I introduce an AR1 term in these models that are estimated with a version of random effects called population averaged models. ${ }^{6}$

As killings of police officers are infrequent and using rates in analyses of rare events is problematic (Osgood, 2000), ${ }^{7}$ the relationships are tested using negative binomial regression, which is designed to estimate unusual events. ${ }^{8}$ Ordinary least squares provide inconsistent estimates when there are many zero-limit scores in a count dependent variable with a modest mean (Long, 1997), but estimators designed specifically for count outcomes provide consistent estimates (Cameron \& Trivedi, 1986; Long, 1997) and reduce chances of the presence of outliers caused by rare and potentially idiosyncratic events.

\section{Descriptive Statistics}

Table 1 summarizes the expected signs and the means and standard deviations for all variables including overall cross-sectional and overtime variation. I expect positive relationships between most explanatory variables and the dependent variable. Only the presence of a Black mayor is hypothesized to have a negative effect.

The data suggest that there is sufficient overtime variation in the dependent variables to conduct panel analyses. Killings range from a minimum of zero in many cases to a high of 6. Most of the cities with many police killings are also those that reported the most police killings of citizens, lending some support to the retaliation argument. ${ }^{9}$ Cities with more Blacks have more homicides of police as nearly all of the 10 cities with the largest number of officer killings have Black populations that are well above the national average.

Due to nonreporting issues, the total number of cases is 302 city-years (recall that each "year" is actually the sum of killings over 3 years). ${ }^{10}$ The sample contains 249 cases (73\%) with no killings of police and 45 cases (13\%) with only one killing of a police officer, suggesting that the distribution is skewed toward fewer killings. Lethal assaults against the police have decreased over time. Specifically, the average number of killings of police per city declines from .48 in 1981-1983 to .19 in 2001-2003, and this decrease is evident in all regions. ${ }^{11}$ These results do not support claims that recent increases in restrictions on police use of force against citizens lead to more lethal assaults on police. Increases in the use of bullet-proof vests and better training probably account for a part of these declines. ${ }^{12}$

\section{Additional Bivariate Correlations}

Zero-order correlations between explanatory factors and the dependent variable suggest that all of the correlations between explanatory variables are modest, suggesting 
Table I. Predicted Signs, Means and Standard Deviations

\begin{tabular}{|c|c|c|c|c|c|c|}
\hline Variable & $\begin{array}{l}\text { Predicted } \\
\text { sign }\end{array}$ & & M & $S D$ & Min & $\operatorname{Max}$ \\
\hline \multirow{3}{*}{$\begin{array}{l}\text { Killings } \\
\text { of police }\end{array}$} & & overall & 0.403 & 1.221 & 0.000 & 18.000 \\
\hline & & between & & 0.780 & 0.000 & 6.000 \\
\hline & & within & & 0.940 & -5.597 & 12.402 \\
\hline$\sqrt{ }$ Police & + & overall & 6.320 & 6.362 & 0.000 & 28.151 \\
\hline killings/ & & between & & 4.970 & 0.000 & 19.444 \\
\hline 100,000 & & within & & 4.047 & -5.712 & 22.439 \\
\hline \multirow[t]{3}{*}{$\sqrt{ }$ Murder rate } & + & overall & 3.716 & $1.47 \mid$ & 0.000 & 8.820 \\
\hline & & between & & 1.308 & 0.923 & 7.471 \\
\hline & & within & & 0.703 & 0.917 & 7.132 \\
\hline \multirow[t]{3}{*}{ Ln no. police } & + & overall & 6.407 & 0.931 & 4.934 & 10.269 \\
\hline & & between & & 0.931 & 5.086 & 10.163 \\
\hline & & within & & 0.199 & 5.066 & 7.782 \\
\hline \% African & + & overall & 22.863 & 18.062 & 0.400 & 81.551 \\
\hline \multirow[t]{2}{*}{ American } & & between & & 18.097 & 0.591 & 75.685 \\
\hline & & within & & 3.853 & -8.547 & 51.305 \\
\hline \multirow{3}{*}{$\begin{array}{l}\% \text { families } \\
\text { in poverty }\end{array}$} & + & overall & 13.394 & 5.174 & 3.900 & 29.900 \\
\hline & & between & & 4.865 & 5.084 & 26.057 \\
\hline & & within & & 1.842 & 6.569 & 20.616 \\
\hline \multirow[t]{3}{*}{ Unemployment } & + & overall & 6.554 & 2.949 & 1.400 & 19.700 \\
\hline & & between & & 2.493 & 3.100 & 15.600 \\
\hline & & within & & 1.722 & -1.779 & 11.321 \\
\hline \multirow{3}{*}{$\begin{array}{l}\text { Median family } \\
\text { income }\end{array}$} & + & overall & 415.969 & 80.984 & 250.417 & 768.669 \\
\hline & & between & & 72.549 & 270.976 & 669.765 \\
\hline & & within & & 34.589 & 300.156 & 534.152 \\
\hline \multirow[t]{3}{*}{ Income ratio } & - & overall & 0.801 & 0.145 & 0.381 & 1.217 \\
\hline & & between & & 0.111 & 0.536 & 1.128 \\
\hline & & within & & 0.098 & 0.528 & 1.088 \\
\hline \multirow[t]{3}{*}{ Segregation } & $+1-$ & overall & 64.432 & 15.685 & 16.850 & 91.900 \\
\hline & & between & & 12.296 & 32.317 & 88.500 \\
\hline & & within & & 9.864 & 26.126 & 98.736 \\
\hline African & - & overall & 0.118 & 0.323 & 0.000 & 1.000 \\
\hline \multirow{2}{*}{$\begin{array}{l}\text { American } \\
\text { mayor }\end{array}$} & & between & & 0.266 & 0.000 & 1.000 \\
\hline & & within & & 0.203 & -0.055 & 0.784 \\
\hline \multirow[t]{3}{*}{ Population } & + & overall & $419,465.000$ & $690,067.700$ & $95,658.000$ & $7,322,564.000$ \\
\hline & & between & & $750,570.100$ & $95,732.000$ & $7,197,102.000$ \\
\hline & & within & & $60,084.080$ & $3,959.026$ & $731,929.000$ \\
\hline
\end{tabular}

that multicollinearity may not be a problem. ${ }^{13}$ Population size and the log of the total number of sworn police are positively related to killing of police. Although these associations do not hold constant other potential explanatory factors, they tentatively suggest that killings of police are more likely in the largest cities with the most officers. A more theoretically interesting finding is that racial residential segregation has a positive effect, tentatively suggesting that violence against the police is most likely in places where Blacks reside apart from Whites. The multivariate analyses will determine if these results persist after holding constant the effects of alternative accounts. 
Table 2. Negative-Binomial Estimates of the Total Number of Homicides of Police in U.S. Cities $(n=302$ City-Years)

\begin{tabular}{|c|c|c|c|c|c|c|}
\hline & \multicolumn{2}{|c|}{ Model I } & \multicolumn{2}{|c|}{ Model 2} & \multicolumn{2}{|c|}{ Model 3} \\
\hline & $b$ & SE & $b$ & SE & $b$ & SE \\
\hline$\sqrt{ }$ Police killings/ 100,000 & 0.019 & 0.018 & 0.019 & 0.018 & $0.030 * *$ & 0.018 \\
\hline$\sqrt{ }$ Murder rate & 0.162 & 0.114 & 0.120 & 0.118 & 0.099 & 0.121 \\
\hline Ln no. police & $0.740 * * * *$ & 0.193 & $0.768 * * * *$ & 0.205 & $0.807 * * * *$ & 0.208 \\
\hline \% Black & $0.027 * * *$ & 0.011 & $0.027 * * *$ & 0.009 & $0.025 * * *$ & 0.010 \\
\hline$\%$ families in poverty & -0.036 & 0.034 & & & & \\
\hline Unemployment & -0.066 & 0.066 & $-0.102 * *$ & 0.062 & $-0.100 *$ & 0.061 \\
\hline Income ratio & $2.244 * *$ & 1.107 & $1.978 * *$ & $1.04 \mid$ & $1.921 * *$ & 0.973 \\
\hline Median Family Income & & & -0.447 & 1.913 & -0.701 & 1.970 \\
\hline Segregation & -0.014 & 0.012 & -0.017 & 0.012 & $-0.050 * * *$ & 0.018 \\
\hline Segregation $\times 1990$ & & & & & $0.05 \mathrm{I} * * *$ & 0.021 \\
\hline Segregation $\times 2000$ & & & & & $0.036 * *$ & 0.020 \\
\hline African American mayor & $-0.734 * *$ & 0.411 & $-0.730 * *$ & 0.403 & $-0.876 * *$ & 0.418 \\
\hline Population & 0.000 & 0.000 & $0.000 * *$ & 0.000 & 0.000 & 0.000 \\
\hline \multicolumn{7}{|l|}{ Region/year controls } \\
\hline East northcentral & 0.938 & 0.706 & 0.907 & 0.699 & 0.866 & 0.667 \\
\hline East southcentral & $1.486 * *$ & 0.757 & $1.355^{* *}$ & 0.747 & $1.296 * *$ & 0.710 \\
\hline Mid-Atlantic & 1.075 & 0.753 & 0.957 & 0.739 & 0.783 & 0.717 \\
\hline South-Atlantic & $1.189 * *$ & 0.696 & I.05| & 0.681 & 0.995 & 0.660 \\
\hline West southcentral & $1.894 * * *$ & 0.696 & $1.747 * * *$ & 0.676 & $1.650 * * *$ & 0.632 \\
\hline Mountain & $1.427 * *$ & 0.761 & $1.379 * *$ & 0.743 & $1.135 * *$ & 0.684 \\
\hline New England & 0.307 & 1.257 & 0.138 & 1.222 & $0.000 * *$ & 1.215 \\
\hline Pacific & $2.028 * * *$ & 0.831 & $2.001 * * *$ & 0.840 & $1.673 * *$ & 0.757 \\
\hline I if 1990 & $-0.632 * *$ & 0.341 & $-0.703 * * *$ & 0.320 & $-4.206 * * *$ & $|.57|$ \\
\hline I if 2000 & $-0.908 * *$ & 0.503 & $-1.174 * * *$ & 0.465 & $-3.768 * * *$ & $\mathrm{I} .464$ \\
\hline Constant & $-8.374 * * * *$ & 1.779 & $-7.846 * * * *$ & 1.652 & $-5.294 * * *$ & I.774 \\
\hline
\end{tabular}

Notes: Coefficients and SEs for Population multiplied by 100,000. Coefficients and SEs for Median Family Income multiplied by I,000.

${ }^{*} p<.1 .{ }^{*} p p<.05 .{ }^{* * *} p<.01 . * * * * p<.00 \mathrm{I}$. (2-tailed tests on intercepts and period dummy variables)

\section{Negative Binomial Regression Results}

Table 2 presents the negative binomial regression analyses of counts of homicides of police officers. The first model includes the variables testing the four main political hypotheses and controls. Variables gauging environmental violence include police killings of citizens, the murder rate, the unemployment rate, and poverty rate. In this model, I find some support for race-specific political explanations. Three out of four political hypotheses are supported. Consistent with hypotheses, the percentage of the population that is African American and the ratio of Black-to-White incomes are positively associated with the number of killings of police whereas having an African American mayor is negatively related to killings of police. However, segregation is 
not related to these killings. Specifically, incidence ratios for the most comprehensive model (not reported but available on request) indicate that having a Black mayor decreases a city's rate of killings of police by a factor of .547 , holding all other variables constant.

None of the variables gauging environmental violence are important. The murder rate and killings of citizens by the police rates are not related to killings of officers in this model. Measures of environmental disorder (the poverty and unemployment rates) also do not matter.

As the two measures are highly correlated, in Model 2, I replace the poverty rates with median family income. This new variable does not predict killings of police, but the substitution does not affect the findings of the prior model.

Segregation is not a significant predictor of killings of police in these first two models, but the hypotheses predict that this variable should affect the outcome differently depending on period. To test this proposition, Model 3 includes the respecification of segregation using period interactions for 1990 and 2000. As predicted, segregation has a negative effect on killings of police in 1980 and a positive effect in 1990 and 2000. The other three political variables continue to predict killings of police in this comprehensive model. All but one of the variables measuring environmental violence and disorder remain ineffective. In this final, most comprehensive model, police killings of citizens is positively related to killings of police. Specifically, a one unit increase in police killings of citizens increases the incidence of killings of officers by a factor if 1.03 .

\section{Additional Tests}

The above models reflect the most important factors related to killings of police. Yet prior studies incorporated different or additional measures. A complete examination of this outcome requires that these measures should be considered. For the sake of parsimony, additional variables were included in models not shown. Additional political variables including the type of city government and the size of the Hispanic population are not important, and their inclusion in the models does not alter the conclusions. Replacing violent and/or property crimes with the murder rates does not affect the results, so murder rates are included because they are more accurately measured. To see whether overall economic inequality is a better predictor of killings compared to racial inequality, a Gini index computed on household incomes was substituted for Black-White income inequality. This indicator of overall inequality did not significantly affect the outcome and did not alter other theoretically important relationships. If crowding, divorce rates, percentage born in state (a measure of residential stability), or population density to gauge disorderly acts not enumerated in official crime rates are entered, the findings persist, but model explanatory power is reduced. Additional statistical interactions do not explain this outcome.

The persistence of these results after using diverse models implies that the findings represent the most important underlying processes that determine killings of police. 
The findings suggest that the largest cities and those with highest Black populations and greater recent killings of citizens by police are more likely to experience killings of police officers whereas cities with Black mayors have less killings. It follows that these analyses support political explanations, but they also suggest that some kinds of community violence contribute to killings of police.

\section{Discussion}

\section{Political Explanations}

The findings provide support for the four main research questions. First, a positive relationship between race-based income differences and killings of officers provides some support for the latent political hypothesis that economic competition between Blacks and Whites may produce violence directed at government agents. Second, racial threat as measured by the size of the Black population has a positive relationship with this outcome. Yet this study found more nuanced effects of racial threat regarding segregation. Consistent with expectations, the most segregated cities had less killings of police in 1980 but more killings in 1990 and 2000. Violence against the police is more common in the most segregated cities, perhaps because racial threat is exacerbated in places with high concentrations of racial minorities. Yet this relationship is present only since 1990. One possible interpretation of this time-contingent finding is that changes in policing tactics, including the rise in community based and public-order policing that assign additional officers to the most crime-ridden places (which in most cities are heavily populated by racial minorities), may have increased officers' exposure to violence that may be politically motivated. But this conclusion assumes that the adoption of community policing necessarily translated into significant changes to officers' activities on the street, a claim which cannot be substantiated with quantitative evidence.

Perhaps there are other reasons that segregated cities had more killings of police in 1990s and 2000s compared to the 1980s. Wilson and Zhao (2008) found that police agencies that met frequently with community groups had lower rates of injurious assaults of officers, yet they also reported higher rates of assault in departments that boasted high drug-arrest rates. The authors suggest that the war on drugs has deteriorated police-citizen relationships. Although this study cannot account for changes in policing strategies, if aggressive law enforcement against drug crimes increased in segregated cities as the war on drugs escalated in the 1990s, it is plausible that policecitizen relationships account for some killings of police officers during this period.

Prior research disagreed on the importance of segregation as it relates to violence against the police (Kaminski, 2004). But these studies only investigated this relationship in one period. The findings from this dynamic analysis suggest that segregation is an important macrosocial factor that deserves further attention in homicide studies. Future studies should investigate the time-specific effects of segregation to identify alternative explanations for this dynamic relationship. 
Finally, cities with Black mayors had less killings of police officers lending support to the supposition that when democratic efficacy is apparent, citizens may feel less inclined to use violence to express political grievances. This relationship persists across diverse model specifications, and it is significant in all three decades, although its effect on killings of police is rather small. This finding bolsters Jacobs and Carmichael (2002) by corroborating an association between Black mayors and killings of police. ${ }^{14}$

\section{Environmental Violence Explanations}

While overall murder rates do not affect homicides of police, in the most comprehensive model, the more direct measure of threat to police, the rate of police killings of citizens, was effective. A positive relationship between police killings of citizens and subsequent killings of officers at the macro level does not necessarily suggest that all or even most homicides of officers are retaliatory, so any application to microlevel policecitizen interactions must be inferred. Prior research has not extensively studied the frequency of retaliatory police homicides, but a content analysis of the summaries of officer homicides reported by the FBI indicates that on average for the years in this analysis, approximately $15 \%$ of felonious killings of officers occurred in ambush situations. Within these ambush killings, about $5 \%$ were entrapment related or premeditated, and the remaining $10 \%$ composed of unprovoked attacks, suggesting that at least some offenders specifically target officers. Future studies of lethal violence against the police should test for this reactive relationship.

Contrary to expectations, some urban conditions (median family income, poverty, and unemployment) that are correlated with disorderly behavior that is not enumerated in official crime rates are not associated with killings of police. These results are contrary to those of some previous studies which reported that indicators of structural disadvantage like poverty and broken homes (Peterson \& Bailey, 1988), concentrated disadvantage (Kaminski, 2008), or divorce rates (Jacobs \& Carmichael, 2002) explained these killings. Yet this discrepancy is not surprising if the effects of structural disadvantage on killings of police are dependent on the unit of analysis and period under investigation (Kaminski, 2004).

\section{Limitations}

Although the results suggest that race differences in political power contribute to killings of police, this relationship is indirect because macrolevel analyses cannot detect individual behavioral responses, so it is difficult to know the exact mechanisms that precipitate officer homicides. Consequently, readers should beware of the ecological fallacy, as no conclusions regarding the micro-level process that surrounds lethal police-citizen encounters can be drawn from these results. Even though political responses at the micro level must be inferred, robust effects of macrolevel indicators explain how structural effects may affect killings of police. 
One of the more important substantive conclusions concerns the findings involving racial composition and segregation. Robust relationships between the size and distribution of the Black population relative to Whites and killings of police after other important factors are held constant indicates that race-based explanations are integral in identifying variations in officer homicides across cities. While these findings may suggest that some police killings stem from racial competition, there is an alternative explanation. Kaminski (2004) uses the percentage of the population that is Black as an indication of the "community disadvantage" that is associated with a high level of violence that increases officer risk because "rates of violent crime tend to be especially high in poor, black, urban communities" (p. 30). Rather than an indication of racial threat, a positive correlation between the size of the Black population and police killings may instead support the environmental violence explanation that attributes killings of police to their exposure to motivated offenders.

Finally, although it is the best available source for information on killings of officers, the LEOKA has been criticized because it relies on the reports of individual agencies and may therefore be less than complete. Given this limitation, the results of this study can only be generalized to the present sample of large cities.

\section{Broader Implications}

In addition to strengthening support for latent political hypotheses that attribute violence against state agents to economic inequality or racial competition, this study shows the utility of direct political explanations by finding that killings of the police are less likely in cities with Black mayors. This finding partly supports arguments that disadvantaged groups are less likely to have the political power necessary to express grievances through conventional channels and must resort to violence to make their political opinions known (Jenkins \& Schock, 1992; Tilly, 1978). This analysis of multiple periods and recent data suggest that such relationships persist in the earliest years of the 21st century. Although it is premature to suggest that increasing the political representativeness of minorities could alleviate violence against the police, more research on whether minority candidates affect sentiments of political efficacy among their constituents is warranted.

More generally, this study isolated some relationships between macrolevel characteristics and police killings that were undetected in previous microlevel studies that examined individual motivations for violent behavior. This investigation suggests that killings of police have a structural basis. From a policy standpoint, changing the socioeconomic and political arrangements of large cities is a difficult and expensive way to reduce killings of police. At the very least, these findings suggest that policies aimed at reducing violence against the police should consider the role of broader political and structural community characteristics in addition to the use of individual officer training and protective technologies.

This study also represents one of few attempts to assess political explanations for reactions to state control efforts. Criminologists have expended considerable effort testing explanations for social control efforts including arrest rates (Gove, Sullivan, 
\& Wilson, 1998), the size of prison populations (Chiricos \& Delone, 1992; Jacobs \& Helms, 1996), police force size (Jacobs \& Helms, 1997; Kent \& Jacobs, 2005; Stucky, 2005), and the use of deadly force by the police (Sorenson, Marquart, \& Brock, 1993; Jacobs \& O’Brien, 1998; Smith, 2003). These studies assessed variations in the application of social control as a result of shifts in the economic and racial factors, but few have considered whether such politically based factors affect reactions to authorities who are responsible for social control. Prior research treated the targets of social control as passive figures, but to fully understand the use of coercive force by the state, responses to social control should not be neglected. This study suggests that political arrangements contribute to the lethal violence used against the police.

\section{Acknowledgments}

The author would like to thank J. Craig Jenkins, Richard Lundman, Wendy Regoeczi, and the anonymous reviewers for their insightful comments on earlier versions of this article.

\section{Declaration of Conflicting Interests}

The authors declared no potential conflicts of interests with respect to the authorship and/or publication of this article.

\section{Funding}

The authors declared no financial support for the research and/or authorship of this article.

\section{Notes}

1. As one can combine both cross-sectional and overtime variation, panel data also create more variability, alleviating potential multicollinearity problems (Kennedy, 2003). Compared to cross-sectional studies, this study incorporates more cases which increases statistical power and improves the ability to detect statistical relationships.

2. Programs such as Compstat involve allocating officers spatially according to the way crime is distributed as gauged from computerized crime maps while community-based policing assigns more officers to the most crime-ridden areas within cities to improve community abilities to control crime and disorder. A 2004 Police Foundation study reports that Compstat has "widely diffused across the landscape of American policing" (p. 6). A third of departments surveyed had a program in place, and an additional quarter were in the process of implementation. New programs increased after publicity of New York's program in 1994 with a peak in 1998.

3. Segregation is measured using an index of dissimilarity which is based on the odds that any Black will come into contact with any White.

4. While the SHR has been criticized as an incomplete source for data on killings of citizens by police, it is the only complete source for a large sample of cities over the period analyzed in this study. Estimates suggest that the SHR underestimates killings (Loftin, Wiersema, McDowall, \& Dobrin, 2003), so correlations with the dependent variable should not overestimate the effect of this explanatory variable. 
5. Stata provides a method to control for the risk of outcomes in count models. But the exposure and offset options do not allow the risk variable to be log transformed. As theory suggests it is important to log the number of sworn police, this variable must instead be included in the model as a control.

6. A population-averaged, random effects estimator is employed to correct for serial correlation and heteroskedasticity.

7. With the exception of Jacobs and Carmichael (2002), prior studies analyzed rates of homicides of police, but rates are not the best way to model rare events. The inflated rates produced by a small number of killings of officers in a relatively small department increase the potential for heteroskedasticity because small city variances will inevitably be greater than those for larger cities (Osgood, 2000). Using raw numbers of killings and an estimation technique designed for modeling counts should produce more reliable estimates.

8. According to the POISGOF test in Stata version 8, overdispersion is present in the data. Negative binomial regression is therefore preferable over Poisson regression because the former allows for overdispersion. Based on a reviewer's useful suggestion that overdispersion may be due to omitted variables, thus leading to exaggerated parameter estimates, the models were rerun using Poisson. All significance levels and directions of relationships between explanatory variables and the dependent variable were consistent with the negative binomial estimates presented.

9. Cities with the highest number of officer homicides include Chicago with 6 in the 1980 period and New York with 5 in the 1990 panel. These cities had high numbers of killings of citizens by police in corresponding census years with an average of 95 and 102, respectively. More than half of citizens killed were African Americans (67 and 53, respectively).

10. Missing cases were due to cities failing to report information in Law Enforcement Officers Killed and Assaulted (LEOKA) for various years. As data on killings of police are reported monthly in the LEOKA file, and because 3 years of data were summed in each panel, cities with less than 8 months of data for at least one of the 3 years in a panel were dropped entirely from that panel. This resulted in a total of 132 cities covered, with 89 cities with information on all 3 panels of data, but the method used does not require balanced panels. Data on killings of officers may therefore be underestimated, which poses less bias than overestimates of rare crimes.

11. The total number of killings of officers across panels ranges from 72 in 1980 to 59 in 1990 , and 54 in 2000. The average number of police killed is highest in Northeastern cities in 2 of the 3 periods and lowest in southern cities. Interestingly, this finding does not correspond with previous studies that found the lowest rate of police homicides in the northeast and the most homicides in the south (Cardarelli, 1968).

12. The DuPont corporation which manufactures the Kevlar fabric used in soft body armor claims that at least 200 officers' lives were saved between 1972, when the products went on the market, and 1992 (Geller \& Scott, 1992). Yet Lott (2000) and others found no relationship between mandatory vest-wearing policies and homicides of officers, suggesting that those who wear vests may take bigger risks that offset their protective effect.

13. In addition, in the best count model, the maximum VIF score is well below the threshold value of 4 which is considered a conservative indication of collinearity. 
14. While overall effects are small, after holding all other variables at their means, cities with Black mayors have a lower predicted number of killings than those without Black mayors.

\section{References}

Bailey, W. C., \& Peterson, R. D. (1994). Murder, capital punishment, and deterrence: A review of the evidence and an examination of police killings. Journal of Social Issues, 50(2), 53-74.

Bayley, D. (1985). Patterns of Policing. New Brunswick, NJ: Rutgers University Press.

Blalock, H. (1967). Toward a theory of minority group relations. New York: Capricorn Books.

Bobo, L., \& Gilliam, F. D. (1990). Race, sociopolitical participation, and Black empowerment. American Political Science Review, 84, 377-393.

Boswell, T., \& Dixon, W. (1990). Dependency and rebellion: A cross-national analysis. American Sociological Review, 55, 540-559.

Cameron, A. C., \& Trivedi, P. K. (1986). Econometric models based on count data: Comparisons and applications of some estimators and tests. Journal of Applied Econometrics, 1, 29-53.

Cardarelli, A. P. (1968). An analysis of police killed by criminal action: 1961-1963. Journal of Criminal Law, Criminology and Police Science, 59, 447-453.

Chiricos, T. G., \& Delone, M. A. (1992). Labor surplus and punishment: A review and assessment of theory and evidence. Social Problems, 39, 421-446.

Clark, T. N. (1994). Race and class versus the new political culture. In T. N. Clark (Ed.), Urban innovation (pp. 21-78). Thousand Oaks, CA: SAGE.

Collins, R. (1975). Conflict sociology. New York: Academic Press.

Federal Bureau of Investigation. (various years). Law enforcement officers killed and assaulted. Ann Arbor: University of Michigan, ICPSR.

Fyfe, J., Greene, J.R., William F. Walsh, W.F., Wilson, O.W., and McLaren, R.C. 1997. Police Administration, 5th ed. McGraw Hill.

Garland, D. (1990). Punishment and modern society. Chicago: University of Chicago Press.

Geller, W. A., \& Karales, K. J. (1981). Split-second decisions: Shootings of and by Chicago Police. Chicago: Chicago Law Enforcement Study Group.

Geller, W. A., \& Scott, M. S. (1992). What we know: A practitioner's desk reference on police involved shootings. Washington, DC: Police Executive Research Forum.

Gove, W. R., Sullivan, P., \& Wilson, J. (1998, August). How are income inequality, poverty, and race related to the crime rates and the control of crime? Paper presented at the Society for the Study of Social Problems meeting, San Francisco.

Jacobs, D., \& Carmichael, J. T. (2002). Subordination and violence against state control agents: Testing political explanations for lethal assaults against the police. Social Forces, 80, 1223-1251.

Jacobs, D., \& Helms, R. (1996). Towards a political model of incarceration. American Journal of Sociology, 102, 323-357.

Jacobs, D., \& Helms, R. (1997). Testing coercive explanations for order: The determinants of law enforcement strength over time. Social Forces, 75, 1361-1392.

Jacobs, D., \& O'Brien, R. (1998). The determinants of deadly force: A structural analysis of police violence. American Journal of Sociology, 103, 837-862. 
Jacobs, D., \& Wood, K. (1999). Interracial conflict and interracial homicide: Do political and economic rivalries explain White killings of Blacks and Black killings of Whites? American Journal of Sociology, 105, 157-190.

Jenkins, J. C., \& Schock, K. (1992). Global structures and political processes in the study of domestic political conflict. Annual Review of Sociology, 18, 161-185.

Johnston, J., \& DiNardo, J. (1997). Econometric methods. New York: McGraw-Hill.

Kaminski, R. J. (2004). The murder of police officers. New York: LFB Scholarly.

Kaminski, R. J. (2008). Assessing the county-level structural covariates of police homicides. Homicide Studies, 12, 350-380.

Kaminski, R. J., \& Stucky, T. (2009). Reassessing political explanations of murders of police. Homicide Studies, 13(1), 3-20.

Kennedy, P. (2003). A guide to econometrics. Cambridge, MA: MIT Press.

Kent, S. L., \& Jacobs, D. (2005). Minority threat and police strength from 1980 to 2000: A fixed-effects analysis of nonlinear and interactive effects in large U.S. cities. Criminology, 43, 731-760.

Krivo, L., \& Peterson, R. D. (1996). Extremely disadvantaged neighborhoods and urban crime. Social Forces, 75, 619-648.

LaFree, G. D. (1982). Male power and female victimization: Toward a theory of interracial rape. American Journal of Sociology, 88, 311-328.

LaFree, G. D., \& Drass, K. A. (1997). African-American collective action and crime 1955-91. Social Forces, 75, 835-853.

LaFree, G. D., Drass, K. A., \& O’Day, P. (1992). Race and crime in postwar America: Determinants of African-American and White rates, 1957-1988. Criminology, 30, 157-185.

Lane, R. (1997). Murder in America. Columbus: Ohio State University Press.

Lester, D. (1978). A study of civilian caused murders of police officers. International Journal of Criminology and Penology, 6, 373-378.

Lester, D. (1982). Civilians who kill police officers and police officers who kill civilians: A comparison of American cities. Journal of Police Science and Administration, 10, 384-387.

Liska, A. E. (1992). Social threat and social control. Albany: SUNY Press.

Loftin, C., Wiersema, B., McDowall, D., \& Dobrin, A. (2003). Underreporting of justifiable homicides committed by police officers in the United States, 1976-1998. American Journal of Public Health, 93, 1117-1121.

Long, J. S. (1997). Regression models for categorical and limited dependent variables. Thousand Oaks, CA: SAGE.

Lott, J. R. (2000). Does a helping hand put others at risk? Affirmative action, police departments, and crime. Economic Inquiry, 38, 239-277.

Massey, D. S., \& Denton, N. A. (1993). American apartheid: Segregation and the making of the underclass. Cambridge, MA: Harvard University Press.

Mayhew, B. H., \& Levinger, R. L. (1976). Size and the density of interactions in human aggregates. American Sociological Review, 82, 86-110.

Meyer, K., Magedanz, T., Dahlin, D., and Chapman, S. 1981. "A comparative assessment of assault incidents: Robbery-related, ambush, and general police assaults." Journal of Police Science and Administration, 9, 1-13. 
Osgood, D. W. (2000). Poisson-based regression analyses of aggregate crime rates. Journal of Quantitative Criminology, 16, 21-43.

Peterson, R. D., \& Bailey, W. C. (1988). Structural influences on the killing of police: A comparison with general homicides. Justice Quarterly, 5, 207-233.

Sampson, R. J. (1987). Urban Black violence. American Journal of Sociology, 93, 348-382.

Sampson, R. J., \& Wilson, W. J. (1995). Toward a theory of race, crime, and urban inequality. In J. Hagan \& R. D. Peterson (Eds.), Crime and inequality (pp. 37-54). Palo Alto, CA: Stanford University Press.

Smith, B. W. (2003). The impact if police officer diversity on police-caused homicides. Policy Studies Journal, 31, 147-162.

Sorenson, J. R., Marquart, J. W., \& Brock, D. E. (1993). Factors related to killings of felons by police officers: A test of the community violence hypotheses. Justice Quarterly, 10, 417-440.

Stucky, T. D. (2005). Local politics and police strength. Justice Quarterly, 22, 139-169.

Tilly, C. (1978). From mobilization to revolution. Reading, MA: Addison-Wesley.

Weber, M. (1968). Economy and society (G. Roth \& C. Wittich, Eds.; E. Fischoff et al., Trans.). Berkeley: University of California Press.

Weisburd, D., Mastrofski, S. D., McNally, A. M., Greenspan, R., \& Willis, J. J. (2001). Compstat and organizational change: Findings from a national survey. Report submitted to the National Institute of Justice by the Police Foundation, Washington, DC.

Weisburd, D., Mastrofski, S. D., Greenspan, R., \& Willis, J. J. (2004, April). The growth of CompStat in American Policing [Police Foundation reports]. Washington, DC: Police Foundation.

Wilson, S., \& Zhao, J. (2008). Determining the correlates of police victimization: An analysis of organizational factors on injurious assaults. Journal of Criminal Justice, 36, 461-468. 